\title{
Perbedaan Derajat Kecemasan pada Mahasiswa Baru Preklinik dan Klinik Fakultas Kedokteran Universitas Andalas
}

\author{
Lily Fajriati ${ }^{1}$, Yaslinda Yaunin ${ }^{2}$, Laila Isrona ${ }^{3}$
}

\begin{abstract}
Abstrak
Pendidikan kedokteran dikenal sebagai stressful environment yang dapat menimbulkan kecemasan pada mahasiswa kedokteran. Mahasiswa kedokteran harus menjalani dua fase pendidikan kedokteran yaitu fase pendidikan preklinik dan klinik. Kedua fase pendidikan ini dapat memicu munculnya kecemasan pada mahasiswa kedokteran terutama pada mahasiswa baru. Tujuan penelitian ini adalah membandingkan perbedaan derajat kecemasan antara mahasiswa baru preklinik dan klinik Fakultas Kedokteran Universitas Andalas. Penelitian ini merupakan penelitian analitik observasional menggunakan pendekatan cross sectional dengan jumlah sampel sebanyak 92 responden yang dipilih dengan teknik purposive random sampling dan menggunakan kuesioner Hamilton Rating Scale for Anxiety (HRS-A), kemudian dianalisis dengan menggunakan uji chi-square. Hasil penelitian ini menunjukan pada mahasiswa baru preklinik didapatkan 43 orang $(93,5 \%)$ tidak ada cemas, dua orang $(4,3 \%)$ dengan kecemasan ringan, dan satu orang $(2,2 \%)$ kecemasan sedang. Pada mahasiswa baru klinik didapatkan 39 orang $(84,8 \%)$ tidak ada kecemasan, lima orang $(10,9 \%)$ kecemasan ringan dan dua orang $(4,3 \%)$ mengalami kecemasan sedang. Stressor utama pada mahasiswa preklinik dan klinik adalah kecemasan mengenai proses pembelajaran selama fase pendidikan. Hasil uji statistik chi-square didapatkan $p$ value $=0,315(p>0.05)$ yang artinya tidak didapatkan perbedaan bermakna antara derajat kecemasan antara mahasiswa baru preklinik dan mahasiswa klinik Fakultas Kedokteran Universitas Andalas.
\end{abstract}

Kata kunci: kecemasan, mahasiswa klinik, mahasiswa preklinik, stressor

\section{Abstract}

Medical education system known as a stressful environment. It might cause anxiety for students. Medical students should endured two kind of phases during the college, which are preclinic phase and clinic phase, that could cause anxiety for students, especially for new students. The objective of this study was to compared the difference of anxiety levels between new preclinic students and new clinic students in Medical Faculty of Andalas University. This study was an observational analytic study using cross-sectional design the study on 92 subjects, consisted of 46 new preclinic and 46 new clinic students of Medical Faculty Andalas University. The subjects obtained by purposive random sampling. Data were collected using a HRS-A quetionnaire which was then analyzed with chi-square test. The results of this study indicated the levels of anxiety in new preclinic students. There were 43 (93.5\%) preclinic students without anxiety, two students (4.3\%) hadmild anxiety, one student (2.2\%) with moderate anxiety. New clinic students indicated that 39 students (84.8\%) were not present anxiety, five students (10.9\%) mild anxiety, and two students (4.3\%) were moderate anxiety. The most dominant stressor for the preclinic and clinic students was anxiety during learning process in medical college. The results of chi-square test showed that the $p$ value $=0,315(p=>0,05)$, so that there was no significant difference between the levels of anxiety in new preclinic students and new clinic student in Medical Faculty of Andalas University.

Keywords : anxiety, clinic students, preclinic students, stressor

Affiliasi penulis: 1. Prodi Profesi Dokter FK Unand (Fakultas Kedokteran Universitas Andalas Padang), 2. Bagian Psikiatri FK Unand, 3. Bagian Pendidikan Kedokteran FK Unand
Korespondensi : Lily Fajriati, Email: lilyfajriati@gmail.com, Telp:083181347433 


\section{PENDAHULUAN}

Kecemasan merupakan suatu kondisi yang dapat dialami oleh setiap orang dalam kehidupan sehari-hari, biasanya kecemasan dialami ketika menghadapi hal-hal baru diluar rutinitas atau ketika menghadapi sesuatu yang datang tiba-tiba, misalnya ujian, perubahan lingkungan kerja atau pendidikan, dan perubahan suasana lainnya. ${ }^{1}$ Kecemasan dan depresi yang tidak ditanggulangi berhubungan dengan rendahnya kemampuan bersosoialisasi, meningkatnya kejadian drop out, serta pemikiran dan percobaan bunuh diri pada mahasiswa. ${ }^{2}$

Pendidikan kedokteran dikenal sebagai stressful environment yang dapat berdampak negatif untuk proses akademik, kesehatan fisik dan psikososial mahasiswa, oleh karena itu mahasiswa kedokteran memiliki tingkat kecemasan, depresi dan stress yang lebih tinggi dibandingkan populasi umum pada kelompok usia yang sama. ${ }^{3}$ Kekhawatiran terhadap keuangan, beban kerja, tekanan akademik, buruknya hubungan mahasiswa dan dosen, masalah orangtua dan anak, masalah keluarga, masalah dengan teman sebaya, dan kekhawatiran terhadap masa depan berkontribusi terhadap gannguan mental pada mahasiswa kedokteran. ${ }^{4}$ Kecemasan diperantarai oleh suatu sistem kompleks yang melibatkan sedikitnya sistem limbik (amigdala, hipokampus), talamus, korteks frontal dan norepinefrin (lokus seruleus), serotonin (nucleus rafe dorsal) dan GABA (reseptor GABA berpasangan dengan reseptor benzodiazepin) pada sistem neurokimia. ${ }^{5}$ Beberapa teori psikologis menjelaskan penyebab kecemasan diantaranya teori psikoanalisis (Kecemasan sebagai konflik yang tidak disadari), teori eksistensial dan teori perilaku (kecemasan sebagai akibat kurangnya kendali. $^{6}$

Stuart dan Laraia (1998) dalam buku Stuart dan Sudeen (2007) membagi derajat kecemasan menjadi kecemasan ringan, kecemasan sedang dan kecemasan berat yang memunculkan gejala yang berbeda-beda. $^{7}$ Secara umum kecemasan memiliki dua gejala yaitu gejala subjektif (berhubungan dengan psikologi) biasanya pasien merasa ketakutan, diteror, gangguan fikiran dan perasaan takut mati serta gejala objektif seperti sakit perut, nausea dan vertigo. ${ }^{8}$
Beberapa manifestasi perifer kecemasan adalah diare, pusing, kepala terasa ringan, hiperhidrosis, hiperrefleksia, hipertensi, palpitasi, midriasis pupil, gelisah, sinkop, takikardia, kesemutan di ekstrimitas, tremor, gangguan perut, frekuensi, hesitansi dan urgensi uri. Dalam hal emosi orang kecemasan cenderung memperhatikan hal tertentu didalam lingkungannya dan mengabaikan hal lain untuk menganggap hal tersebut menakutkan. ${ }^{6}$

Tujuan penelitian ini adalah membandingkan perbedaan derajat kecemasan pada mahasiswas baru preklinik dan klinik Fakultas Kedokteran Universitas Andalas.

\section{METODE}

Jenis penelitian yang telah dilakukan ini adalah analitik observasional dengan rancangan penelitian cross-sectional. Penelitian dilakukan pada bulan Januari 2015 - Desember 2015.

Populasi pada penelitian ini adalah seluruh mahasiswa baru FK Unand tahun ajaran 2015/2016 dan mahasiswa yang menjalani tahap klinik sejak 2015. Kedua populasi ini sama-sama mengalami perubahan dalam suasana dan sistem pembelajaran. Namun memiliki stressor psikososial yang berbeda dalam mempengaruhi derajat kecemasan..

Kriteria inklusi pada mahasiswa baru prekliik adalah mahasiswa baru angkatan 2015 yang sedang menjalani blok 1.1, mahasiswa yang sedang menjalani tahap pendidikan preklinik dan bersedia menjadi responden. Kriteria inklusi pada mahasiswa baru klinik yang ditetapkan adalah mahasiswa yang baru menjalani pendidikan klinik pada tahun 2015, mahasiswa klinik yang belum menjalani siklus pendidikan klinik dan bersedia menjadi responden. Kriteria eksklusi adalah memiliki riwayat pengobatan psikiatri.

Besar sampel diperoleh melalui perhitungan dengan rumus :

$$
n=\frac{Z \alpha^{2} P Q}{d^{2}}
$$

$\mathrm{n} \quad$ : jumlah sampel

Za2 : derivat baku normal $\alpha=0,05$ adalah $(1,96)^{2}$

$\mathrm{P} \quad$ : proporsi variabel yang ingin diteliti $(11,7 \%){ }^{9}$

Q $\quad: 1-P=1-0,117=0,913$

d : tingkat ketepatan absolut yang diinginkan (10\%) 


$$
n=\frac{(1,96)^{2}(0,117)(0,913)}{(0,1)^{2}}=41,03=41
$$

Berdasarkan rumus tersebut didapatkan minimal terdapat 41 sampel penelitian. Untuk mengantisipasi kemungkinan subyek terpilih yang drop out digunakan formula sederhana. ${ }^{10}$

$$
n^{\prime}=\frac{n}{(1-f)}
$$

Keterangan :

n' : jumlah subyek yang diteliti

$\mathrm{n} \quad$ : besar sampel yang dihitung

f : perkiraan proporsi drop out (10\%)

$$
n^{\prime}=\frac{41}{(1-0,1)}=45,55=46
$$

Berdasarkan rumus di atas maka jumlah subyek yang akan diteliti adalah 46 orang. Kemudian dikalikan dua kelompok area (Zona Merah dan Zona Hijau), sehingga total sampel yang dibutuhkan sebesar 92 orang.

Teknik pengambilan sampel yang digunakan pada penelitian ini adalah purposive random sampling. pencuplikan random sederhana dilakukan terhadap mahasiswa preklinik dan mahasiswa klinik dimana masing-masing diambil sesuai perhitungan sampel secara acak sehingga masing-masing subyek atau unit populasi memiliki peluang yang sama.

Variabel penelitian terdiri dari variabel independen yaitu mahasiswa Fakultas Kedokteran Universitas Andalas.dan variabel dependen yaitu kecemasan pada mahasiswa.

Analisis data pada penelitian ini menggunakan analisis univariat untuk melihat distribusi frekuensi, analisis bivariat digunakan untuk melihat hubungan antara variabel independen dan variabel dependen dengan menggunakan chi square test dengan taraf $\operatorname{signifikan}(\alpha) \quad 0,05$. Bila $p$-value $<\alpha$ berarti ada hubungan yang bermakna antara kedua variabel.

HASIL

\section{Analisis Univariat}

Jumlah responden dalam penelitian ini sebanyak 46 mahasiswa preklinik dan 46 mahasiswa klinik dengan total 92 mahasiswa kedokteran.
Perempuan lebih banyak menjadi responden penelitian yakni sebanyak 64 orang $(69,6 \%)$ dan yang berjenis kelamin laki-laki sebanyak 28 orang $(30,4 \%)$. Selain itu, kita dapat melihat bahwa responden berusia antara 16-24 tahun dengan rata-rata (mean) usia 19,63 tahun $(S D=2,121)$.

Tabel 1. Distribusi frekuensi derajat kecemasan pada mahasiswa baru preklinik FK Unand

\begin{tabular}{lcc}
\hline Derajat Kecemasan & $\mathbf{f}$ & $\%$ \\
\hline Tidak ada kecemasan & 43 & 93,5 \\
Ringan & 2 & 4,3 \\
Sedang & 1 & 2,2 \\
Berat & 0 & 0 \\
Sangat berat & 0 & 0 \\
\hline Total & 46 & 100 \\
\hline
\end{tabular}

Berdasarkan Tabel 1 bahwa dari 46 responden pada mahasiswa preklinik didapatkan 43 orang $(93,5 \%)$ tidak ada cemas, dua orang $(4,3 \%)$ dengan kecemasan ringan, satu orang $(2,2 \%)$ kecemasan sedang serta tidak ditemukan kecemasan berat dan sangat berat.

Tabel 2. Distribusi frekuensi derajat kecemasan pada mahasiswa baru klinik FK Unand

\begin{tabular}{lcc}
\hline \multicolumn{1}{c}{ Derajat Kecemasan } & f & \% \\
\hline Tidak ada kecemasan & 39 & 84,8 \\
Ringan & 5 & 10,9 \\
Sedang & 2 & 4,3 \\
Berat & 0 & 0 \\
Sangat berat & 0 & 0 \\
\hline Total & 46 & 100 \\
\hline
\end{tabular}

Berdasarkan Tabel 2, maka dari 46 responden pada fase klinik didapatkan 39 orang $(84,8 \%)$ tidak ada kecemasan, lima orang $(10,9 \%)$ kecemasan ringan dan dua orang $(4,3 \%)$ mengalami kecemasan sedang dan tidak ditemukan kecemasan berat dan sangat berat. 
Tabel 3. Stressor kecemasan pada mahasiswa baru preklinik FK Unand

\begin{tabular}{lcc}
\hline Stressor & $\mathbf{f}$ & $\%$ \\
\hline Jauh dari keluarga & 7 & 15,2 \\
Proses pembelajaran selama & 34 & 73,9 \\
$\begin{array}{l}\text { fase preklinik } \\
\text { Ujian }\end{array}$ & 5 & 10,9 \\
\hline Total & 46 & 100 \\
\hline
\end{tabular}

Berdasarkan Tabel 3,dapat dilihat bahwa dari 46 responden pada mahasiswa preklinik didapatkan 34 orang $(73,9 \%)$ mencemaskan bagaimana proses pembelajaran selama menjalani fase preklinik pada FK Unand, tujuh orang $(15,2 \%)$ memiliki stressor cemas yang disebabkan oleh karena harus hidup terpisah dan jauh dari anggota keluarga, lima orang (10,9\%) disebabkan oleh kekhawatiran akan ujian-ujian yang harus dijalani selama pendidikan.

Tabel 4. Stressor kecemasan pada mahasiswa baru klinik FK Unand

\begin{tabular}{lcc} 
Stressor & f & $\%$ \\
Proses pembelajaran selama fase klinik & 37 & 80,4 \\
Perpindahan siklus dan rumah sakit & 3 & 6,5 \\
Kurangnya waktu untuk diri sendiri & 6 & 13,1 \\
Total & 46 & 100 \\
\hline
\end{tabular}

\section{Analisis Bivariat}

Analisis bivariat dilakukan untuk menilai perbedaan pada masing-masing variabel dengan
Berdasarkan Tabel 3,dapat dilihat bahwa dari 46 responden pada mahasiswa preklinik didapatkan 34 orang $(73,9 \%)$ mencemaskan bagaimana proses pembelajaran selama menjalani fase preklinik pada FK Unand, tujuh orang $(15,2 \%)$ memiliki stressor cemas yang disebabkan oleh karena harus hidup terpisah dan jauh dari anggota keluarga, lima orang (10,9\%) disebabkan oleh kekhawatiran akan ujian-ujian yang harus dijalani selama pendidikan.

Berdasarkan Tabel 4,dapat dilihat bahwa dari 46 responden pada mahasiswa klinik didapatkan 37 orang $(80,4 \%)$ mencemaskan bagaimana proses pendidikan selama fase klinik, enam orang $(13,1 \%)$ disebabkan oleh kekhawatiran akan kurangnya waktu untuk diri sendiri dan tiga orang $(6,5 \%)$ karena perpindahan siklus dan rumah sakit. menggunakan uji statistik chi-square dengan taraf $\operatorname{signifikan}(\alpha) 0,05$.

Tabel 5. Hasil uji chi-square antara mahasiswa baru preklinik dan klinik FK Unand

\begin{tabular}{|c|c|c|c|c|c|c|c|c|c|}
\hline & \multicolumn{6}{|c|}{ Derajat Kecemasan } & \multicolumn{2}{|c|}{ Total } & $\mathbf{P}$ \\
\hline & $f$ & $\%$ & $f$ & $\%$ & $f$ & $\%$ & $f$ & $\%$ & \\
\hline Preklinik & 43 & 93,5 & 2 & 4,3 & 1 & 2,2 & 46 & 100 & 0,315 \\
\hline Klinik & 39 & 84,8 & 2 & 4,3 & 5 & 10,9 & 46 & 100 & \\
\hline
\end{tabular}

Tabel 5 menunjukan jumlah mahasiswa preklinik yang tidak cemas 43 orang $(93,5 \%)$, dua orang $(4,3 \%)$ kecemasan ringan, satu orang $(2,2 \%)$ kecemasan sedang. Pada mahasiswa klinik ditemukan 39 orang $(84,8 \%)$ tidak mengalami kecemasan, lima orang $(10,9 \%)$ dengan kecemasa sedang dan dua orang $(4,3 \%)$ mengalami kecemasan ringan. Terlihat bahwa mahasiswa preklinik memiliki persentase tidak cemas lebih tinggi dibandingkan dengan mahasiswa klinik. Hasil uji statistik chi-square menunjukkan nilai $p$ value $=0,315$.

\section{PEMBAHASAN}

Berdasarkan penelitian yang telah dilakukan, diperoleh usia responden berkisar antara usia 16-24 tahun dengan rata-rata usia adalah 19,63 tahun. Jenis 
kelamin terbanyak adalah perempuan yaitu sebanyak 64 orang $(69,6 \%)$ dan laki-laki 28 orang $(30,4 \%)$. Pada penelitian ini, perbedaan usia dan jenis kelamin pada responden dapat mempengaruhi derajat kecemasan pada masing-masing responden. Oleh karena kecemasan dipengaruhi oleh beberapa faktor, diantaranya adalah potensi stressor, maturitas, status pendidikan dan ekonomi, keadaan fisik, tipe kepribadian, sosial budaya, lingkungan dan situasi umur dan jenis kelamin. ${ }^{11}$ Penelitian yang dilakukan oleh Bayram \& Bilge (2008), menunjukan bahwa mahasiswa perempuan memiliki tingkat kecemasan, depresi dan stress yang lebih tinggi dibandingkan mahasiswa pria. ${ }^{12}$

Berdasarkan hasil penelitian didapatkan jumlah mahasiswa baru preklinik sebesar 43 orang (93,5\%) tidak memiliki gejala kecemasan, dua orang $(4,3 \%)$ mengalami kecemasan ringan dan satu orang $(2,2 \%)$ kecemasan sedang. Sedangkan mahasiswa baru fase klinik menunjukan bahwa 39 orang $(84,8 \%)$ tidak memiliki gejala kecemasan, lima orang $(10,9 \%)$ kecemasan ringan dan dua orang (4,3\%) mengalami kecemasan sedang. Dari hasil penelitian ini menunjukkan bahwa terdapat perbedaan derajat kecemasan pada mahasiswa preklinik dan klinik, namun tidak menunjukan perbedaan yang bermakna secara statistik.

\section{Tipe Kepribadian Subjek Penelitian}

Latar somato-psikososial yang berbeda pada subjek penelitian. Daya tahan stress pada setiap orang berbeda-beda, hal ini tergantung pada keadaan somato-psikososial orang itu. ${ }^{13}$ Hasil penelitian ini menunjukan hasil yang berbeda dari penelitian yang dilakukan Widosari (2010) yang mengatakan bahwa terdapat perbedaan derajat kecemasan pada mahasiswa preklinik dan klinik. Hal ini terjadi karena perbedaan latar somato-psikososial subjek penelitian, sehingga hasil penelitiannya pun berbeda. ${ }^{14}$ Dalam penelitian ini belum dapat dipilih subjek penelitian dengan latar somato-psikososial yang sama, karena keterbatasan penelitian.
2. Waktu Pengambilan Sampel Penelitian

Penelitian ini dilakukan pada saat mahasiswa baru mengikuti proses pembelajaran, yaitu pada mahasiswa preklinik, penelitian dilakukan pada minggu pertama tahun ajaran baru, begitu juga pada mahasiswa baru fase klinik, penelitian pada mahasiswa fase klinik dilakukan saat pembekalan untuk menjalani senior clerkship di rumah sakit. Subjek penelitian masih belum mengetahui siklus mana yang akan dijalani, setiap siklus akan mempengaruhi derajat kecemasan pada mahasiswa klinik. Karena belum menjalani siklus di rumah sakit, mahasiswa baru fase klinik belum mengetahui pasti dan merasakan bagaimana proses pembelajaran di fase klinik, oleh karena itu belum muncul kecemasan pada subjek penelitian. Selain itu, kecemasan tidak dapat muncul sampai seseorang sadar terhadap lingkungannya. ${ }^{7}$

Berdasarkan penelitian yang dilakukan, dapat dilihat bahwa dari 46 responden pada mahasiswa preklinik didapatkan 34 orang $(73,9 \%)$ mencemaskan bagaimana proses pembelajaran selama menjalani fase klinik pada FK Unand, yang harus dijalani selama pendidikan. Oleh karena pembelajaran pada pendidikan kedokteran memiliki beban materi pembelajaran yang lebih luas dan rumit dibandingkan dengan materi pembelajaran pada Sekolah Menengah Atas.

Penelitian terdahulu yang serupa pernah dilakukan Widosari (2010) yang meneliti tentang perbedaan derajat kecemasan dan depresi pada mahasiswa preklinik dan ko-asisten. Dari penelitian tersebut didapatkan hasil yang berbeda dengan penelitian ini, dimana hasil penelitian tersebut menyimpulkan bahwa terdapat perbedaan bermakna antara mahasiswa preklinik dan ko-asisten. ${ }^{14}$

\section{SIMPULAN}

Tidak didapatkan perbedaan bermakna antara derajat kecemasan pada mahasiswa baru preklinik dan kinik FK Unand. 


\section{DAFTAR PUSTAKA}

1. Elvira, Sylvia D. 2008. Gangguan panik. Jakarta: Balai Penerbit FKUI; 2008.hlm.1-2.

2. Saravanan C, Wilks R. Medical students' experience of and reaction to stress: the role of depression and anxiety. The Scientific World Journal. 2014

3. Singh I, Jha A. Anxiety, optimism and academic achievement among students of private medical and engineering colleges: a comparative study. Journal of Educational and Developmental Psychology. 2013;3(1): 222-33.

4. Yusoff MS, Abdul RAF, Baba AA. Prevalence and associated factors of stress, anxiety and depression among prospective medical students. Asian Journal of Psychiatry. 2013;6(2):128-33.

5. Tomb A. Buku saku psikiatri (terjemahan). Jakarta: EGC; 2004. hlm.96.

6. Sadock BJ, Sadock VA. Kaplan \& Sadock's: concise tektbook of clinical psychiatry. Edisi ke-3. Philadelphia USA: Lippincott Williams \& Wilkins; 2010.hlm.236.

7. Stuart GW, Sudeen SJ. Buku Saku Keperawatan Jiwa (terjemahan). Edisi 5. Jakarta: EGC; 2007.hlm.175-8, 180-1.

8. Emilien G, Lepola UM, Dinan T. Durlach C. Anxiety disorder: pathophysiological and pharmacological treatment. Bekhauser Verlag: Berlin; 2002.hlm.1.
9. Chandratika D, Purnawati S. Gangguan cemas pada mahasiswa semester i dan semester VII progam studi pendidikan dokter fakultas kedokteran Universitas Udayana. E-jurnal medika udayana. 2014;3(4).

10. Kar N, Mohapatra PK, Nayak KC, Pattanaik P, Swain SP, Kar HC. Post-traumatic stress disorder in children and adolescents one year after a supercyclone in Orissa. Journal of BMC Psychiatry. 2007;7(8): 7-8.

11. Widianti E. Pengaruh logo dan terapi suportif kelompok terhadap ansietas remaja di rumah tahanan dan lembaga pemasyarakatan wilayah provinsi Jawa Barat (tesis). Jakarta: Universitas Indonesia; 2011.hlm.25,59,60.

12. Bayram N, Bilge N. The prevalence and sociodemographic correlations of depression, anxiety and stress among a group of university students. Social Psychiatry and Psychiatric Epidemiology. 2008; 43(8):667-72.

13. Maramis WF. Catatan ilmu kedokteran jiwa. Surabaya: Airlangga University Press. 2005.hlm. 38, 107, 252-4.

14. Widosari WY. Perbedaan derajat kecemasan dan depresi mahasiswa kedokteran preklinik dan koasistensi di FK UNS Surakarta (skripsi). Surakarta: Fakulas Kedokteran Universitas Sebelas Maret; 2010. 